\title{
Virtuální realita a její využití pro tréninky zaměstnanců
}

\author{
Marek Bárdy ${ }^{1}$ \\ ${ }_{1}$ XR Institute s.r.o. \\ Zbrojnická 229/1, 30100 Plzeň \\ bardy@cie-group.cz
}

\begin{abstract}
Anotace: Příspěvek se soustředí na moderní technologii - virtuální realitu a konkrétně pak na její využití pro trénink zaměstnanců. $V$ př́spěvku jsou zdůrazněny výhody plynoucí z využití virtuální reality pro trénink zaměstnanců a následně jsou uvedeny podmínky pro její nasazení v podniku, a to od výběru tématu až po její vlastní implementaci.
\end{abstract}

\section{1 Úvod}

Druhé desetiletí 21 . století se neodmyslitelně nese $v$ duchu digitalizace a optimalizace pracovních procesů. Firmy a jejich personální oddělení se snaží najít způsoby a řešení, do kterých se vyplatí investovat prostředky za účelem zvýšení efektivity vzdělávání a rozvoje zaměstnanců. $V$ dnešní době není jednoduché najít a udržet si kvalitní zaměstnance. Proto většina firem pracuje na rozvoji svých stávajících zaměstnanců a dělá vše proto, aby jejich lidé byli v zaměstnání spokojeni, a aby se jejich kariéra dále rozvíjela. Co je však mnohdy ještě těžší, je vytvoření správného zázemí pro rozvoj zaměstnanců a nalezení toho nejlepšího způsobu předávání informací tak, aby vnímali svůj trénink a rozvoj co možná nejlépe. $V$ tomto odvětví se před několika lety objevila naprosto zásadní inovace, která naplňuje i ty nejpřísnější požadavky zaměstnavatelů - virtuální realita.

\section{Výhody plynoucí z využití virtuální reality pro trénink zaměstnanců}

Virtuální realita (dále VR) je technologie, která nám umožňuje simulovat jakoukoliv situaci, a to bez žádných bezpečnostních či finančních rizik. Díky technologii VR jsme schopni připravit zaměstnance na nejrůznější situace. At' jsou to situace krizové (viz obrázek 1), které nelze nijak simulovat, dokud se reálně nestanou, nebo příprava zaměstnanců na jakékoliv rizikové úkony či důsledné vytvoření správných návyků, které mohou vést ke snížení rizik v ostrém provozu. Další ukázka technologie VT při tréninku zaměstnanců je uvedena na obrázku 2.

Využití virtuální reality ve školení zaměstnanců přináší nespočet výhod, které staví tuto technologii na první přičku způsobů, jakými lze školení provádět. Mezi ty nejzásadnější patří např. naprostá autonomie tréninku, jinak reč̌eno, zaměstnanec se může vzdělávat a rozvíjet kdekoliv a kdykoliv, navíc není 
potřeba prítomnosti žádné další osoby, vše ho naučí specializovaná VR aplikace. Další výhodou využití VR oproti běžným metodám tréninku je to, že dokáže zajistit $100 \%$ pozornost uživatele a úkony $v$ tréninkovém scénáŕi uživatel plní zcela přirozeně a podvědomě, tudíž si zapamatuje mnohem víc informací.

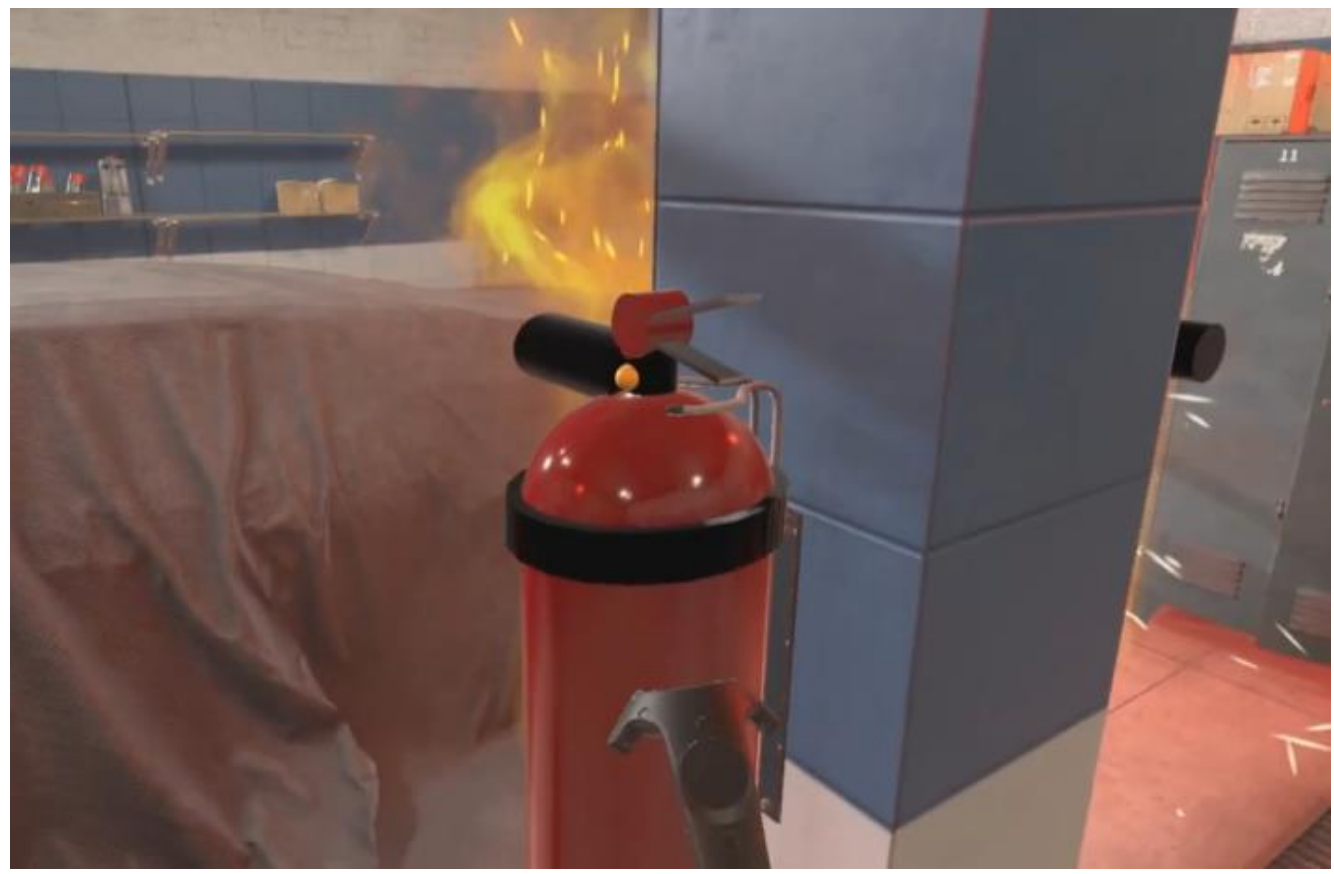

Obrázek 1 - Ukázka virtuální reality pro trénink krizové situace

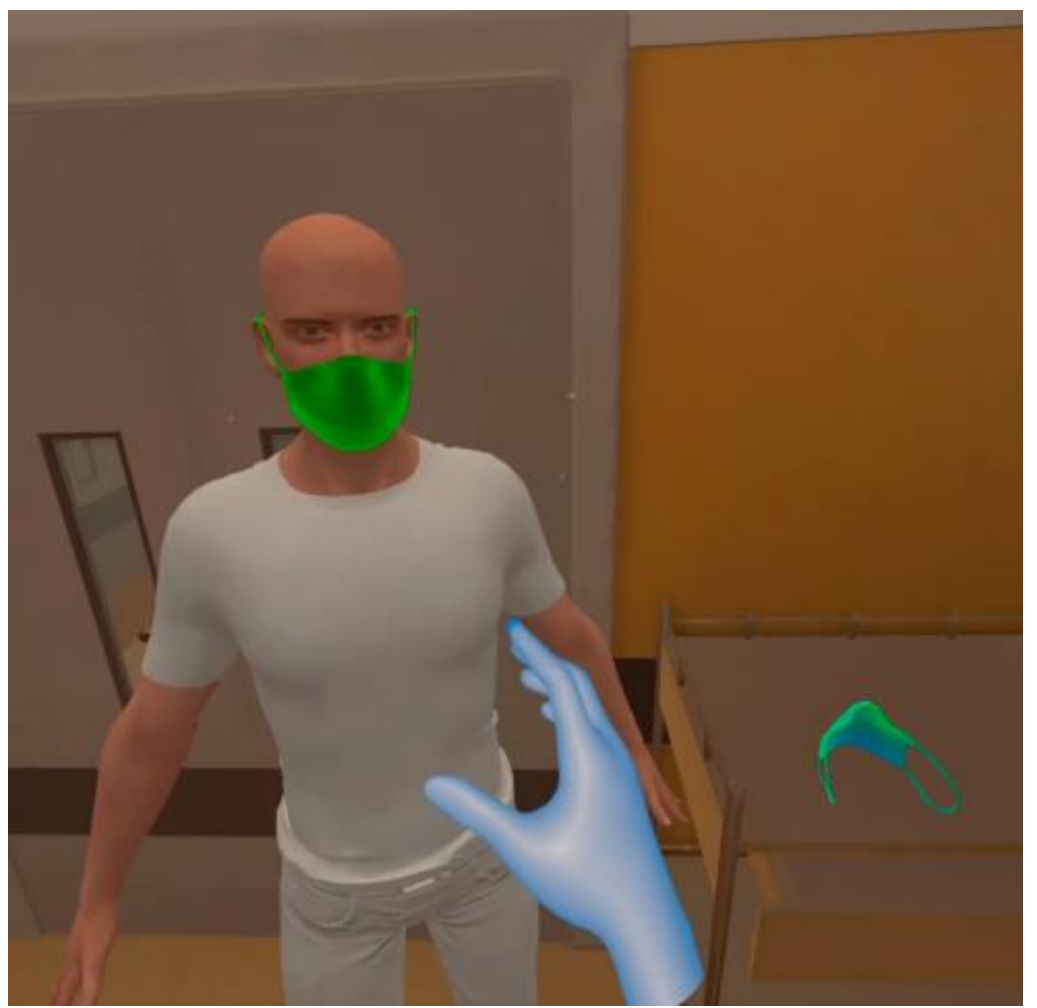

Obrázek 2 - Ukázka virtuální reality pro trénink zaměstance 
Nespornou výhodou je i to, že VR aplikace dokáže dopodrobna sledovat chování uživatele, jeho silné a slabé stránky, podle kterých Ize tréninkové lekce upravovat, opakovat apod. $V$ dnešním době je tato technologie již natolik pokročilá, že si ji Ize snadno pořídit a provozovat bez větších složitostí formou plug \& play. V České Republice existuje odborná společnost XR Institute zabývající se tímto tématem.

\section{$3 \quad$ Podmínky pro nasazení virtuální reality}

Vše začíná už při výběru dodavatele, jelikož využití VR není rozhodně pouze o tom nechat si vyvinout aplikaci a nakoupit potřebný hardware. Doporučuje se dbát na odbornost instituce, která software vyrábí a to hned $z$ několika důvodů. Vytvoření vhodných a funkčních aplikací stojí na čtyřech hlavních pilírích, které rozhodují úspěšnost a efektivitu nasazení VR.

1. Výběr tématu - Technologie VR disponuje vlastnostmi, které jsou zcela nenahraditelné, však není vhodná na veškeré aplikace $z$ důvodů pořizovacích nákladů. Obecně platí, že bychom VR měli nasazovat na procesy, které mají vysokou frekvenci opakovanosti, či procesy, které mají vysoký dopad na bezpečnost, či kvalitu.

2. Odbornost realizačního týmu - U VR platí více než u jiných IT projektů, že dochází k nepochopení zadání, vzhledem k rozdílnosti představ, nedostatečnému technickému backroundu na obou stranách. Proto je vhodné vybírat pouze dodavatele, kteří mají ve svém týmu specialisty na daný obor pro který se scénář připravuje, didaktiky, kteří zaručí funkčnost školení a procesní/projektové inženýry, kteří projekt zvládnou koordinovat.

3. Způsob ovládání - U VR obecně platí, že ovládání není jednoduché a v prípadě, krátkých školení, může jeho osvojení trvat déle než samotné školení. Existují varianty ovládání tzv.: ,Handtracking" , která je zcela intuitivní a není potřeba školení ovládání. Však jeho praktické nasazení dokáží zvládnout jen zkušené firmy. V české republice se jedná o cca tři společnosti. Ukázka způsobu ovládání je uvedena na obrázcích 3 a 4.

4. Implementace VR - Je závěrečný krok pro úspěšné nasazení VR do Vaší společnosti, který však určuje je výsledný efekt. Obecně platí, že každá změna je složitá a to platí i u implementace VR. Je třeba vybrat takového dodavatele, který má zkušenosti a technologie pro výslednou implementaci. Na české i evropském trhu není hodně společností, které mají dostatečné zkušenosti. Zkušené společnosti, poznáte, tak že již v čase prípravy nabídky, řeší i zpưsob implementace, který nastavují na míru zákazníka. Nejdůležitějším aspektem je způsob samotného zapínání VR aplikací a jejich kompletní správa formou platformy, která tyto procesy zajištuje. V současné době existují pouze dvě tyto aplikace, jedná se o aplikaci Grove od stejnojmenné společnosti a VRecosystem od CZ společnosti VR training. Ukázka implementace je uvedena na obrázcku 5. 


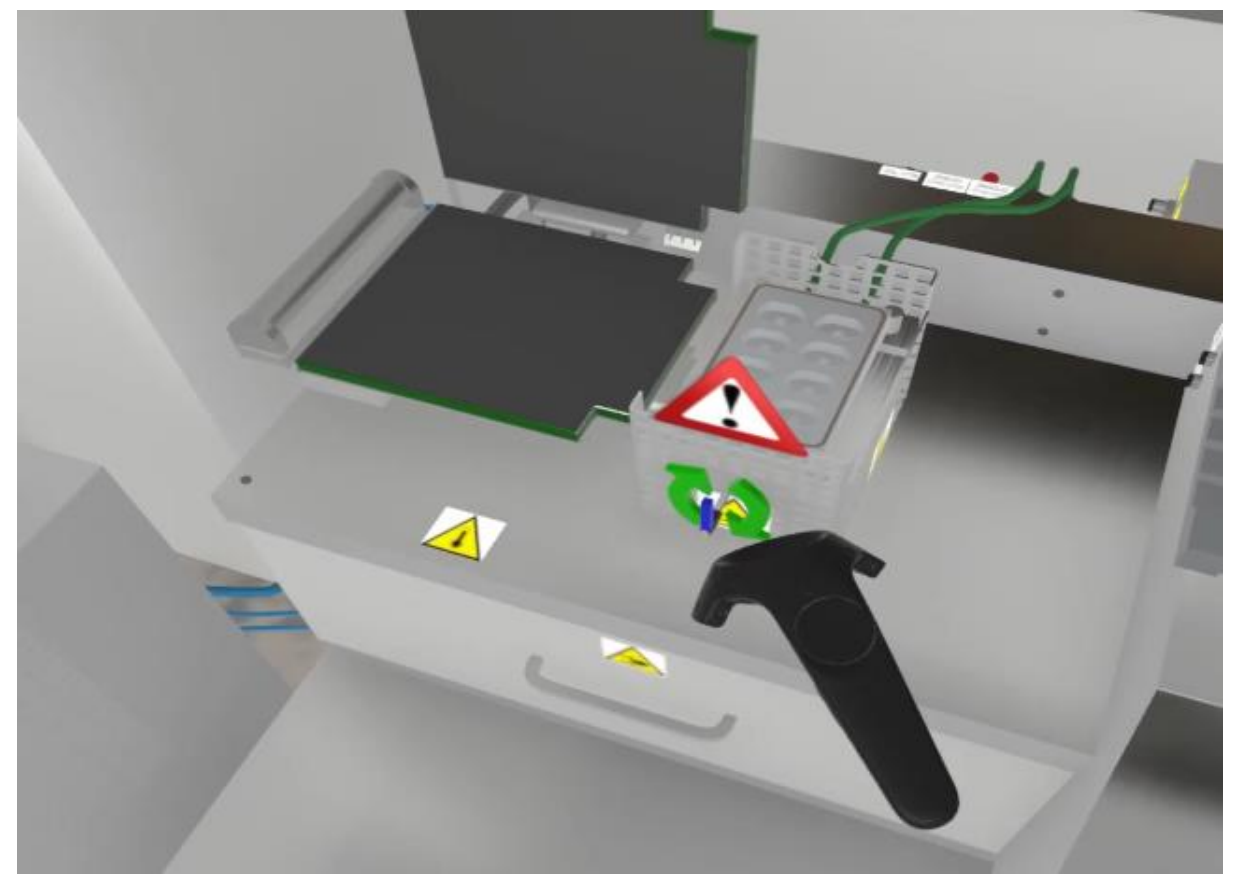

Obrázek 3 - Ukázka způsobu ovládání u virtuální reality

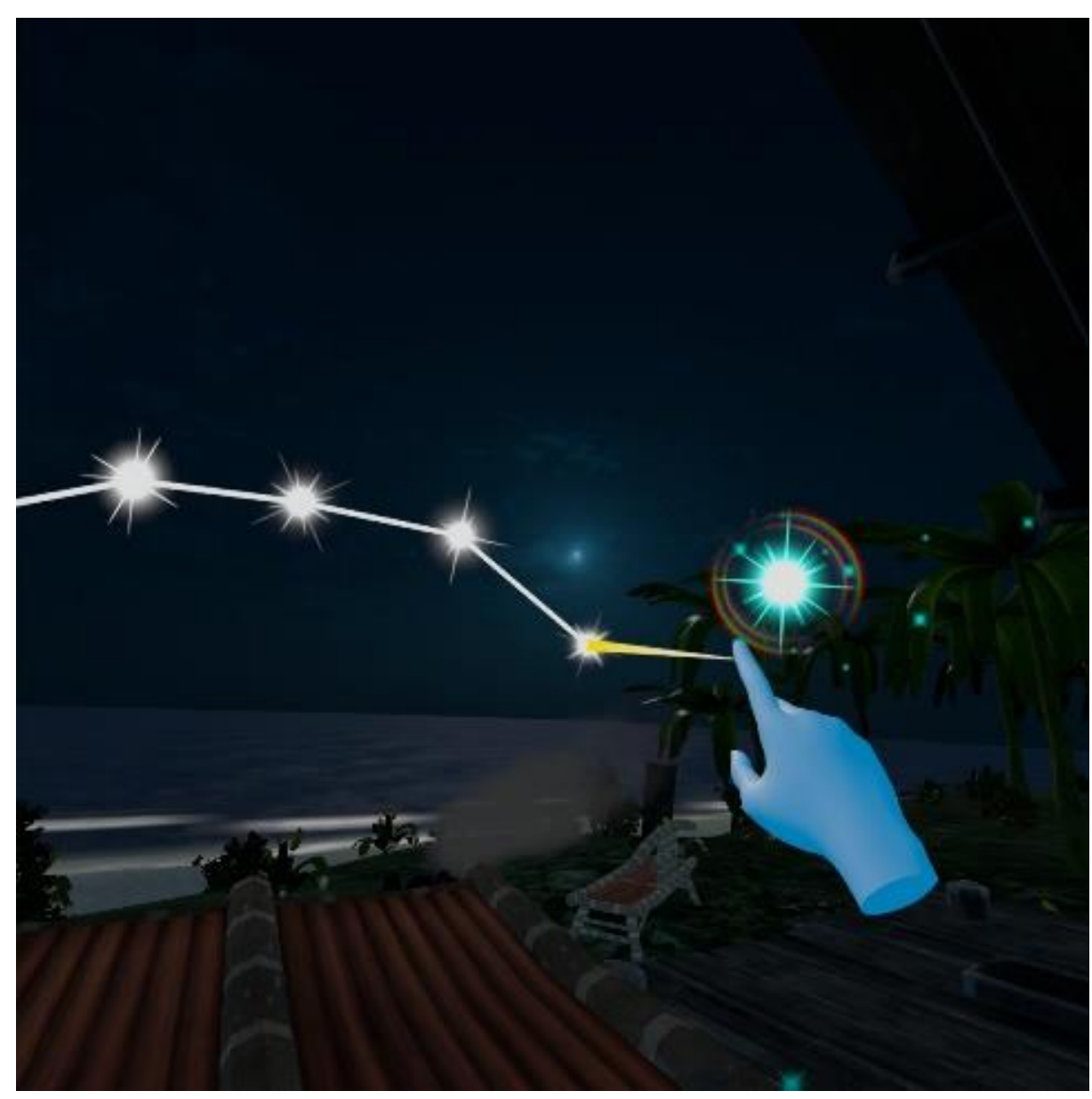

Obrázek 4 - Ukázka způsobu ovládání u virtuální reality 


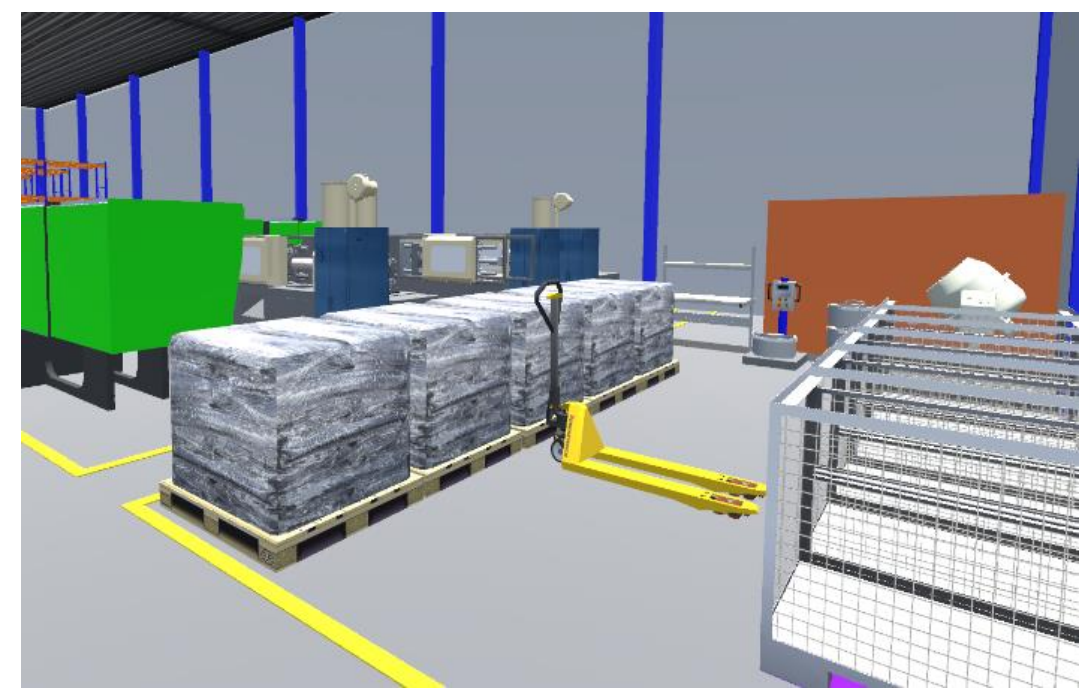

Obrázek 5 - Ukázka implementace virtuální reality v podniku

\section{Závěr}

Na závěr je důležité uvést, že jelikož je virtuální realita pro drtivou většinu firem nová a neprobádaná technologie, není vhodné inned začínat kompletní transformací všech tréninkových procesů, naopak postupným rozvojem vzdělávacího procesu je docíleno kýženého efektu.

\section{Použitá literatura}

[1] Caputo, F. \& Greco, Alessandro \& D'Amato, Egidio \& Notaro, Immacolata \& Spada, S.. (2018). On the use of Virtual Reality for a human-centered workplace design. Procedia Structural Integrity. 8. 297-308. 10.1016/j.prostr.2017.12.031.

[2] KUBR, Jan., N., NOVIKOV, Konstantin, HOREJSI, Petr., KLEINOVA, Jana., \& KRAKORA, David. (2021). Connecting a virtual production and a plc. MM Science Journal, $2021(2), 4452-4462$. https://doi.org/10.17973/mmsj.2021_6_2021007

[3] Grigore C. Burdea Invited Review: The Synergy Between Virtual Reality and Robotics, ieee transactions on robotics and automation, vol.15, no.3, june 1999 